\title{
A content analysis on articles related to English (L2) pronunciation teaching *
}

\author{
Murat Hismanoglu ${ }^{a} \dagger$ \\ APA Citation: \\ ${ }^{a}$ Usak University, Faculty of Arts and Science, Usak 64100, Turkey
}

Hismanoglu, M. (2019). A content analysis on articles related to English (L2) pronunciation teaching. Journal of Language and Linguistic Studies, 15(2), 633-648.

Submission Date: 2019/03/15

Acceptance Date: 2019/05/17

\begin{abstract}
This study aimed at analyzing the articles on English (L2) pronunciation teaching published between 2012 and 2017. To achieve this purpose, 106 articles in fourteen well-known international journals in the field of foreign language learning and teaching were examined. These journals were indexed by SSCI $(\mathrm{f}=7)$, ERIC ( $\mathrm{f}=4)$, EBSCO $(\mathrm{f}=2)$ and MLA $(\mathrm{f}=1)$ databases in international platforms. These articles were analyzed in terms of research type, research topic, target population, sample selection method, sample size, research method, data collection method, data analysis method, language of articles, year of publication, authors, number of references, and most frequently used keywords. The paper classification form [PCF], originally designed by Sözbilir, Kutu \& Yasar (2012) and adapted into the field of English Language Teaching by Yagiz, Aydin \& Akdemir (2016) was utilized by the researcher to collect data on the content of articles. The results displayed the general scope of research studies on English (L2) pronunciation teaching in international contexts.
\end{abstract}

(c) 2019 JLLS and the Authors - Published by JLLS.

Keywords: English (L2); pronunciation; teaching; content analysis; pronunciation teaching

\section{Introduction}

Pronunciation is a key component in successful L2 oral communication (Rajadurai, 2007). Being able to articulate the sounds of a foreign language accurately is as crucial to effective L2 communication as the expansion of vocabulary knowledge or the correct use of grammatical rules (Martinsen, Alvord \& Tanner, 2014). As Fraser (2000) states, with good pronunciation, a speaker's speech can be comprehensible despite having lexical, grammatical and pragmatic mistakes; however, with bad pronunciation, his/her speech can be very hard to comprehend despite being correct in other areas. In this vein, it can be stated that pronunciation teaching is of great prominence for the realization of effective L2 oral communication in that pronunciation is a significant component of the communicative competence (Hismanoglu, 2006).

Despite its significance in successful L2 oral communication, some L2 learners encounter a number of problems with pronunciation due to a wide range of factors. Therefore, it is prominent to take into

\footnotetext{
* A preliminary version of this study was presented at Global Education, Teaching \& Learning Conference, 26-29 September 2018, Dubrovnik, Crotia.

${ }^{\dagger}$ Corresponding author. Tel.: +90-276-221 2134

E-mail address: murat.hismanoglu@usak.edu.tr
} 
account these affecting factors. At this point, many researchers attempted to list the factors affecting native-like L2 pronunciation (Gilakjani, 2012; Piske, Flege \& MacKay, 2001; Tanner, 2012) While the factors like age, ear perception, aptitude, personality, attitude, motivation, identity, individual efforts and goal setting were accepted as internal factors, the factors like the L2 learner's native language, exposure to the target language and educational factors were accepted as external factors (Zhang, 2009).

In this study, the articles on English (L2) pronunciation teaching published in fourteen well-known foreign language learning and teaching related international journals between the years 2012-2017 were analyzed by using the method of content analysis. The names of the analyzed journals and the number of analyzed articles in each journal are shown in table 1 below:

Table 1. The names of analyzed journals

\begin{tabular}{llll}
\hline Name of the journal & Indexing & $\mathrm{f}$ & $\%$ \\
\hline 1. ELT Journal (ISSN 0951-0893) & & 3 & 2.8 \\
2. TESOL Quarterly (ISSN 1545-7249) & SSCI & 8.5 \\
3. Language Teaching (ISSN 0261-4448) & SSCI & 9 & 1.9 \\
4. Foreign Language Annals (ISSN 1944-9720 & SSCI & 10 & 9.4 \\
5. The Modern Language Journal (ISSN 1540-4781) & SSCI & 3 & 2.8 \\
6. System (ISSN 0346-251X) & SSCI & 13 & 12.3 \\
7. Language Learning and Technology (ISSN 1094-3501) & SSCI & 3 & 2.8 \\
8. TESL Canada Journal (ISSN 0826-435X) & ERIC & 1 & 0.9 \\
9. CALICO Journal (ISSN 2056-9017) & ERIC & 3 & 2.8 \\
10. Studies in Second Language Acquisition (ISSN 1470-1545) & ERIC & 26 & 24.5 \\
11. Journal of Language and Linguistic Studies (ISSN 1305-578X) & ERIC & 3 & 2.8 \\
12. Journal of Language Teaching and Research (ISSN 2053-0684) & EBSCO & 11 & 10.4 \\
13. Theory and Practice in Language Studies ((ISSN 2053-0692) & EBSCO & 13 & 12.3 \\
14. Language Teaching Research (ISSN 1477-0954) & MLA & 6 & 5.7 \\
& & & 100 \\
\hline Total & & 106 \\
\hline
\end{tabular}

\subsection{Literature review}

The history of foreign language teaching methodology witnessed striking fluctuations concerning the role of pronunciation. In the grammar-translation method, the main focus was on developing reading and writing skills. However, there was no emphasis on teaching pronunciation. In the direct method, pronunciation was very important. The supporters of this method indicated that learners could learn pronunciation without getting any specific instruction following a period of listening and internalizing of the L2 sound system (Ketabi \& Saeb, 2015).

In 1940s and 1950s, the audio-lingual method and situational language teaching were very popular. There was a strong emphasis on pronunciation in these two methods because of being affected by the principles of the Reform Movement. The concepts of pronunciation, minimal pairs, drills and short conversations were stressed (Celce-Murcia \& Goodwin, 1991). In 1960s, the cognitive approach was in the front seat of the instructional agenda in the EFL classroom. According to Richards \& Rodgers (2001), this approach was supported by Chomsky's theory of transformational generative grammar and it stimulated learners to utilize their innate and creative abilities to find out the underlying grammatical rules of the language. This approach disregarded pronunciation in the EFL classroom.

In the late 1970s, the emergence of the Communicative Language Teaching (CLT) gave rise to the weakening of the position of pronunciation in this period (Couper, 2008; Isaacs, 2009). In the early 1980s, pronunciation was generally dropped from communicative instruction because the proponents of 
CLT assumed that teaching pronunciation based on accuracy and meaningless drills would give harm to communicative practice (Binte Habib, 2013). However, in the later stages of its advancement, communicative approach altered its view on pronunciation teaching. Pronunciation was accepted to be a basic component of communicative competence and it was indicated that pronunciation should be emphasized in the EFL classroom. (Jenkins, 2004).

During 1990s and the early 2000s, intelligibility, suprasegmentals and lingua franca core were the major topics of interest in L2 pronunciation teaching. In the nativeness principle, the aim of most L2 pronunciation teaching programs until the 1960s was to achieve a native like mastery of the target sound system. However, in the intelligibility principle, the aim of most L2 pronunciation teaching programs during 1990s and the early years of 2000s was to reach a comprehensible speech because having a native like pronunciation was not possible for all EFL learners. As Ketabi \& Saeb (2015) state, the development of CLT, the global spread of English as an international language, the flourishment of the notion of World Englishes and the increase in international communications for trade, political and cultural purposes were some of the factors which paved the way for placing intelligibility into the heart of most L2 pronunciation teaching programs. Levis (2005) indicated that suprasegmentals (e.g. stress, pitch, juncture and intonation) also attracted pronunciation teachers and researchers during these years.

In 2000s, the Lingua Franca Core (LFC) was deployed as a tool to display the characteristics of English pronunciation. The aim of LFC was to enable speakers with different L1 backgrounds to be more intelligible to one another (Setter, 2006). In 2005, the development of the audio-articulation method by Demirezen contributed to the strengthening of the place of pronunciation in this period. Demirezen (2005) developed this method so as to rehabilitate the wrong articulations of problematic sounds by Turkish EFL learners. In the audio-articulation method, the primary focus was on phonemes, minimal pairs, minimal sentences and sentences with contextual clues. However, the suprasegmental aspects were not emphasized in it (Geylanioglu \& Dikilitas, 2012).

After 2010s, the research topics like the effects of instruction on L2 pronunciation, the effects of phonology on L2 pronunciation and computer assisted pronunciation teaching gained popularity within the field of L2 pronunciation teaching. In our times, many EFL teachers are unwilling to teach L2 pronunciation to their students due to not having adequate knowledge of phonetics and phonology, lack of suitable pronunciation teaching materials and limited time in the foreign language program (Harmer, 2001). It is obvious that pronunciation receives less attention than other language skills such as listening, speaking, reading and writing in foreign language teaching programs.

Despite receiving less attention than other four language skills in today's foreign language teaching programs, pronunciation is closely related with the ability to listen, speak, read and write. If EFL learners know the sounds and the prosodic features of the target language adequately, they can perceive and produce L2 specific words, phrases and utterances successfully and hence they can have good oral communication (Gebhard, 1996; Varasarin, 2007). Similarly, if EFL learners use orthographic analogies when reading new words (e.g. using 'heat' as a guide for reading 'beat'), they can read these new words accurately (Goswami, 2000).

Lastly, if EFL learners know that there is no one-to-one sound and letter relationship in English, they can write English words accurately. In English, there are five main areas of sound and spelling inconsistencies. Firstly, EFL learners should learn that the same letter does not always indicate the same sound (e.g. the letter $\mathrm{c}$ is pronounced as $/ \mathrm{k} / \mathrm{as}$ in cap [kæp] and /s/ as in ceiling [si:lin]). Secondly, they should learn that the same sound is not always indicated by the same letter (e.g. the voiceless labio-dental fricative /f/ is spelled as $\mathrm{f}$ as in fat [fæt], ph as in photo [foutor] and gh as in cough [ka:f]. Thirdly, they should learn that there are words having silent letters in English (e.g. the letter $\mathrm{k}$ is silent as in knee [ni:]. Fourthly, they should learn that inserting a sound where there is no sound (e.g. 
pronouncing / $\mathrm{j} /$ before $\mathrm{u}$ as in university [ju:nəvз:səti], cue [kju:]) is problem causing for non-native EFL learners. Fifthly, the articulations of the plurality (e.g. /s/: hats [hæts], /z/: bags [bægz], /əz/: buses

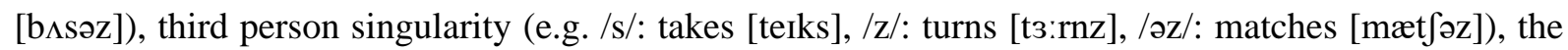
possessivity (e.g. /s/: Kate's [keIts], /z/: Ted's [tedz], /əz/: George's [dzə:rdzəz], and the past tense (e.g. /t/: kissed [kIst], /d/: begged [begd], /əd/: planted [plæntəd]) morphemes are problematic for non-native EFL learners (Hismanoglu, 2004; Umera-Okeke, 2008).

As for the place of pronunciation in our current English language education program, it can be stated that L2 pronunciation is not incorporated into English language education program from the $2^{\text {nd }}$ grade to the $8^{\text {th }}$ grade. However, it is integrated into English language education program in the $9^{\text {th }}, 10^{\text {th }}, 11^{\text {th }}$ and $12^{\text {th }}$ grade levels. While there is a limited pronunciation practice in the $9^{\text {th }}, 11^{\text {th }}$ and $12^{\text {th }}$ grade levels, there is a special emphasis on pronunciation practice in $10^{\text {th }}$ grade level (Hismanoglu, 2019).

\subsection{Purpose and problem}

The observed problem that makes the researcher conduct this study is that there are some studies focusing on the content analysis of the articles related to (a) foreign language education in Turkey in general (Alptekin \& Tatar, 2011; Solak, 2014; Yağız, Aydın \& Akdemir, 2016), (b) English language teacher education (Avalos, 2011; Demir \& Koçyiğit, 2018; Kleinsasser, 2013; Vélez-Rendón, 2002), (c) strategy training in L2 learning (Mutlu, 2015), (d) graduate research on ELT in Turkey (İnal, Özdemir, Kıray \& Oral, 2016; Koçyiğit \& Erdem, 2018; Özmen, Cephe, \& Kınık, 2016), (e) teaching English with technology (Hussein, 2015), (f) using flipped classroom in foreign language education (Ahmed \& Asiksoy, 2018; Filiz \& Benzet, 2018), (g) assessment and evaluation in foreign language teaching in Turkey (Arslan \& Kartal, 2018), (h) teaching L2 listening (Dewitt-Brinks \& Rhodes, 1992) and (i) teaching L2 reading (Akaydın \& Cecen, 2015; Parsons \& Gallagher, 2016) in the literature. However, there are no research studies regarding the content analysis of the articles related to teaching L2 pronunciation. Hence, the purpose of the present study is to complete this gap in the literature and identify the most common interests of researchers in the field of English (L2) pronunciation teaching so as to pave the way for the direction of future research.

At this point, in parallel to the purpose of this study, the following research questions guide this research:

1. How are the articles distributed according to their research type?

2. How are the articles distributed according to their research topics?

3. How are the articles distributed according to their target population?

4. How are the articles distributed according to sample selection method?

5. How are the articles distributed according to sample size?

6. How are the articles distributed according to research method?

7. How are the articles distributed according to data collection method?

8. How are the articles distributed according to data analysis method?

9. How are the articles distributed according to language of articles?

10. How are the articles distributed according to year of publication?

11. How are the articles distributed according to authors?

12. How are the articles distributed according to references?

13. How are the articles distributed according to key words? 


\section{Methodology}

\subsection{Sample}

106 research articles related to English (L2) pronunciation teaching published in fourteen wellknown international journals in the field of foreign language learning and teaching were included in the study. These fourteen international journals were indexed by SSCI ( $\mathrm{f}=7$ ), ERIC ( $\mathrm{f}=4$ ), EBSCO ( $\mathrm{f}=2$ ) and MLA ( $\mathrm{f}=1)$ databases in international platforms.

\subsection{Instrument}

In this study, a paper classification form [PCF], originally designed by Sözbilir, Kutu \& Yasar (2012) and adapted into the field of English Language Teaching by Yagiz, Aydin \& Akdemir (2016) through the examination of the sources (websites, journals and books) according to the disciplinary contents of the form, was used by the researcher to gather data on the content of articles related to English (L2) pronunciation teaching. In content analysis, the categorization of the content is prominent (Uysal \& Madenoglu, 2015). The categories used in the present study were research type, research topic, target population, sample selection method, sample size, research method, data collection method, data analysis method, language, publication year, authors, references and key words.

\subsection{Data collection procedure}

To collect data for the present study, articles related to English (L2) pronunciation published in fourteen foreign language learning and teaching related international journals between the years of 2012 and 2017 in the data base of EBSCO were scanned. The scanning was limited with 'L2 pronunciation', 'English (L2) pronunciation teaching' key words and years from 2012 to 2017. Hence, 106 articles were found and they were analyzed by the method of content analysis.

\subsection{Data analysis procedure}

In the present study, each article was analyzed in terms of content. The content of each article was categorized into previously determined themes. Also, the results were displayed in frequency and percentage tables.

\section{Results}

\subsection{Research type}

Table 2 displays the research type inclination of the articles. It is clearly seen that quantitative research is the most frequently used research type by researchers with a frequency of 79 out of 106 articles $(74.5 \%)$. However, mixed method is the least frequently used research type by researchers with a frequency of 9 out of 106 articles $(8.5 \%)$.

Table 2. Distribution of articles according to research type

\begin{tabular}{lll}
\hline Research type & $\mathrm{f}$ & $\%$ \\
\hline Qualitative research & 18 & 17 \\
Quantitative research & 79 & 74.5 \\
Mixed method & 9 & 8.5 \\
Total & 106 & 100 \\
\hline
\end{tabular}




\subsection{Research topic}

After examining the articles according to their research topics, the researcher identified 20 research topic categories ranging from the effects of instruction on L2 pronunciation to L2 pronunciation assessment, views on L2 pronunciation and non-native EFL learners' pronunciation strategies. As seen in table 3, 'Effects of Instruction on L2 pronunciation' was the most frequently researched topic with a frequency of 19 out of 106 articles (17.9\%). 'Effects of phonology on L2 pronunciation' was the second most frequently researched topic with a frequency of 11 out of 106 articles $(10.4 \%)$. 'Computer assisted pronunciation teaching' was the third most frequently researched topic with a frequency of 9 out of 106 articles $(8.5 \%)$. However, topics like 'accent and identity relationship', 'non-native EFL learners' pronunciation strategies', 'the effect of study abroad context on nativelike pronunciation' and 'the effects of native and non-native teachers of English on learners' pronunciation performance' were the least frequently researched topics with a frequency of 1 out of 106 articles $(0.9 \%)$.

Table 3. Distribution of articles according to research topics

\begin{tabular}{lll}
\hline Research topics & $\mathrm{f}$ & $\%$ \\
\hline 1. Effects of instruction on L2 pronunciation & 19 & 17.9 \\
2. Effects of phonology on L2 pronunciation & 11 & 10.4 \\
3. Computer assisted pronunciation teaching & 9 & 8.5 \\
4. Corrective feedback & 8 & 7.5 \\
5. Comprehensibility & 7 & 6.6 \\
6. L2 pronunciation teaching techniques & 7 & 6.6 \\
7. Teachers' knowledge & 5 & 4.7 \\
8. Factors affecting L2 pronunciation & 4 & 3.8 \\
9. L2 pronunciation assessment & 4 & 3.8 \\
10. Teaching suprasegmental features & 4 & 3.8 \\
11. Attitudes towards L2 pronunciation & 3 & 2.8 \\
12. Views on L2 pronunciation & 2 & 1.9 \\
13. English accents & 2 & 1.9 \\
14. Production and perception problems & 2 & 1.9 \\
15. The place of pronunciation in teaching materials & 2 & 1.9 \\
16. Accent and identity relationship & 1 & 0.9 \\
17. Non-native EFL learners' pronunciation strategies & 1 & 0.9 \\
18. The effect of study abroad context on nativelike pronunciation & 1 & 0.9 \\
19. The effects of native and non-native teachers of English on & 1 & 0.9 \\
learners' pronunciation performance & & 12.3 \\
20. Others & 13 & \\
\hline Total & & 106 \\
\hline
\end{tabular}

\subsection{Target population}

As displayed in table 4, the most frequently used target population in the articles consisted of undergraduate students with a frequency of 59 out of 106 articles $(55.7 \%)$. Nevertheless, the least frequently used target population in the articles was composed of primary school students with a frequency of 1 out of 106 articles $(0.9 \%)$. 
Table 4. Distribution of articles according to target population

\begin{tabular}{lll}
\hline Target population & $\mathrm{f}$ & $\%$ \\
\hline Primary school students & 1 & 0.9 \\
Secondary school students & 3 & 2.8 \\
High school students & 6 & 5.7 \\
Undergraduate students & 59 & 55.7 \\
Graduate students & 3 & 2.8 \\
Teachers & 6 & 5.7 \\
Others & 15 & 14.2 \\
Not stated & 13 & 12.3 \\
& & \\
\hline Total & 106 & 100 \\
\hline
\end{tabular}

\subsection{Sample selection method}

As seen in table 5, the most frequently used sample selection method in the articles was nonprobability sampling method with a frequency of 52 out of 106 articles (49.1\%). However, the least frequently used sample selection method in the articles was whole population with a frequency of 11 out of 106 articles $(10.4 \%)$.

Table 5. Distribution of articles according to sample selection method

\begin{tabular}{lcc}
\hline Sample selection method & $\mathrm{f}$ & $\%$ \\
\hline Probability sampling method & 23 & 21.7 \\
Non-probability sampling method & 52 & 49.1 \\
Whole population & 11 & 10.4 \\
Sampling method not stated & 20 & 18.9 \\
\hline Total & 106 & 100 \\
\hline
\end{tabular}

\subsection{Sample size}

As seen in table 6, the most frequently used sample size in the articles was between 31-100 with a frequency of 44 out of 106 articles $(41.5 \%)$. Nevertheless, the least frequently used sample size in the articles was between 301-1000 with a frequency of 3 out of 106 articles (2.8\%).

Table 6. Distribution of articles according to sample size

\begin{tabular}{lll}
\hline Sample size & $\mathrm{f}$ & $\%$ \\
\hline $1-10$ & 7 & 6.6 \\
$11-30$ & 29 & 27.4 \\
$31-100$ & 44 & 41.5 \\
$101-300$ & 10 & 9.4 \\
$301-1000$ & 3 & 2.8 \\
Not stated & 13 & 12.3 \\
\hline Total & 106 & 100 \\
\hline
\end{tabular}




\subsection{Research method}

Table 7 shows the research method inclination in the articles. Experimental method which was one of quantitative methods was the most frequently used research method with a frequency of 75 out of 106 articles $(70.7 \%)$. However, case study which was one of qualitative methods was the least frequently used research method with a frequency of 3 out of 106 articles $(2.8 \%)$.

Table 7. Distribution of articles according to research method

\begin{tabular}{lll} 
Research method & $\mathrm{f}$ & $\%$ \\
\hline QUANTITATIVE METHOD & 75 & 70.7 \\
$\begin{array}{l}\text { Experimental } \\
\text { Quasi-experimental }\end{array}$ & 4 & 3.8 \\
QUALITATIVE METHOD & 15 & 14.2 \\
Review & 3 & 2.8 \\
Case study & 9 & 8.5 \\
MIXED METHOD & 906 \\
\hline Total & 106 \\
\hline
\end{tabular}

\subsection{Data collection methods}

As seen in table 8, the most frequently used data collection methods in the articles were others (picture story, picture differences task, conversation task, oral test, word / sentence / paragraph / dialogue / short story reading, video recording, videotaped presentations, recording scripted and semispontaneous speech, oral discourse completion task, focus group discussions) with a frequency of 29 out of 106 articles. Nevertheless, the least frequently used data collection method in the articles was achievement test with a frequency of 2 out of 106 articles. Percentage values were not calculated in that more than one data collection method may have been utilized in one research study.

Table 8. Distribution of articles according to data collection method

\begin{tabular}{ll}
\hline Data collection methods & $\mathrm{f}$ \\
\hline QUESTIONNAIRE/SCALE & 3 \\
Open ended & 17 \\
Likert & 1 \\
Other & $\mathbf{2 1}$ \\
Subtotal &
\end{tabular}

\section{ACHIEVEMENT TEST}

Open ended

Multiple choice $\quad 1$

Other

Subtotal

1

2

PERCEPTION/ATTITUDE/SKILL TESTS

8

\section{INTERVIEW}

Constructed

Semi-constructed

Unconstructed 
Focus group

Subtotal
1

15
OBSERVATION

Participatory

Non-participatory

Subtotal

\section{1}

6

7

\section{ALTERNATIVE TOOLS}

(Diagnostic test, conceptual maps, portfolios, sound perception and 24 production tests)

\section{DOCUMENTS}

15

OTHERS (picture story, picture differences task, conversation task, oral test, word/sentence/paragraph/dialogue/short story reading, video recording, videotaped presentations, recording scripted and semispontaneous speech, oral discourse completion task, focus group discussions)

\subsection{Data analysis method}

As seen in table 9, the most frequently used data analysis method in the articles was descriptive analysis method. In descriptive analysis method, the use of graphic display ( $\mathrm{f}=50$ ) was the most commonly used procedure. In 65 research studies, inferential data analysis methods were utilized. In inferential data analysis methods, the use of ANOVA/ANCOVA ( $\mathrm{f}=31)$ was the most commonly used procedure. However, inferential data analysis methods like Chi-square $(\mathrm{f}=3)$, non-parametric tests $(\mathrm{f}=3)$ factor analysis $(\mathrm{f}=1)$ were very few in number. As regards the qualitative analysis methods, qualitative descriptive analysis $(\mathrm{f}=25)$ was used more frequently than content analysis $(\mathrm{f}=3)$. Percentage values were not calculated because more than one data collection method may have been utilized in one research study.

Table 9. Distribution of articles according to data analysis method

\begin{tabular}{lc}
\hline Data analysis method & $\mathrm{f}$ \\
\hline QUANTITATIVE DESCRIPTIVE & \\
Frequency/Percentage & 23 \\
Mean/Standard Deviation & 48 \\
Graphic Display & 50 \\
Other & 1 \\
\hline
\end{tabular}

\section{QUANTITATIVE INFERENTIAL}

Correlation

Factor Analysis

Regression 
Qualitative Descriptive Analysis

\subsection{Language of articles}

As seen in table 10, all of the articles were written in English with a frequency of 106 out of 106 articles.

Table 10. Distribution of articles according to article language

\begin{tabular}{lcc}
\hline Article Language & $\mathrm{f}$ & $\%$ \\
\hline English & 106 & 100 \\
\hline Total & 106 & 100 \\
\hline
\end{tabular}

\subsection{Year of publication}

As seen in table 11, 2016 was the year when the number of published articles was the highest with a frequency of 25 out of 106 articles (23.6\%). However, 2013 and 2015 were the years when the number of published articles was the lowest with a frequency of 11 out of 106 articles (10.4\%).

Table 11. Distribution of articles according to year of publication

\begin{tabular}{lll}
\hline Year of publication & $\mathrm{f}$ & $\%$ \\
\hline 2012 & 17 & 16 \\
2013 & 11 & 10.4 \\
2014 & 22 & 20.8 \\
2015 & 11 & 10.4 \\
2016 & 25 & 23.6 \\
2017 & 20 & 18.9 \\
\hline Total & 106 & 100 \\
\hline
\end{tabular}

\subsection{Authors}

As displayed in table 12, 46 of the articles were written by one author (43.4\%). 36 of the articles were written by two authors (34\%). 19 of the articles were written by three authors (17.9\%). Lastly, 5 of the articles were written by more than three authors $(4.7 \%)$.

Table 12. Distribution of articles according to their author number

\begin{tabular}{llll}
\hline Authors & $\mathrm{f}$ & $\%$ \\
\hline & 1 author & 46 & 43.4 \\
& 2 authors & 36 & 34 \\
& 3 authors & 19 & 17.9 \\
& 3+ authors & 5 & 4.7 \\
\hline Total & & 106 & 100 \\
\hline
\end{tabular}




\subsection{References}

As displayed in table 13, the most frequently used reference number in the articles was between 31-60 with a frequency of 49 out of 106 articles (46.2 \%). Nevertheless, the least frequently used reference number in the articles was between 101-101+ with a frequency of 3 out of 106 articles (2.8 $\%)$.

Table 13. Distribution of articles according to their reference number

\begin{tabular}{lll}
\hline Reference number & $\mathrm{f}$ & $\%$ \\
\hline $1-30$ & 27 & 25.5 \\
$31-60$ & 49 & 46.2 \\
$61-100$ & 27 & 25.5 \\
$101-101+$ & 3 & 2.8 \\
\hline Total & 106 & 100 \\
\hline
\end{tabular}

\subsection{Key words}

After analyzing the articles according to their key words, the researcher identified 27 key word categories ranging from pronunciation to pronunciation teaching / pronunciation instruction / pronunciation training, phonetics instruction / phonetic training, intelligibility / comprehensibility, vowels / vowel perception / vowel production and consonants / consonant perception. As displayed in table 14, pronunciation was the most frequently used key word with a frequency of 29 out of 106 articles. 'Foreign accent / accentedness' was the second most frequently used key word with a frequency of 10 out of 106 articles. 'Pronunciation teaching / pronunciation instruction / pronunciation training' was the third most frequently used key word with a frequency of 9 out of 106 articles. However, key words like 'native like pronunciation', 'fluency', 'pronunciation strategies', 'phonological development' and 'pronunciation self-assessment' were the least frequently used key words with a frequency of 1 out of 106 articles. Percentage values were not calculated in that 3 to 5 key words were utilized in one research study.

Table 14. Distribution of articles according to key words

\begin{tabular}{ll}
\hline Key word(s) & $\mathrm{f}$ \\
\hline 1.pronunciation & 29 \\
2. foreign accent/accentedness & 10 \\
3. pronunciation teaching/pronunciation instruction/pronunciation training & 9 \\
4.phonetics & 6 \\
5. computer assisted language learning & 6 \\
6. suprasegmentals & 6 \\
7. phonology & 5 \\
8. perception/perception problem/L2 perception & 5 \\
9. intelligibility/comprehensibility & 5 \\
10. second language acquisition & 5 \\
11. Vowels/vowel perception/vowel production & 4 \\
12. accent/English accents/British \& American English & 4 \\
13. corrective feedback & 4 \\
14. direct/explicit/form-focused instruction & 4 \\
15. English as a lingua franca & 4 \\
16. phonetics instruction/phonetic training & 4 \\
17. production/oral production/production problem & 3 \\
18. fossilization/fossilized/pronunciation errors & 3 \\
19. study abroad & 3
\end{tabular}


20. Consonants/consonant perception 2

21. attitudes towards pronunciation $\quad 2$

22. identity 2

23. native like pronunciation 1

24. fluency 1

25. pronunciation strategies 1

26. phonological development 1

27. pronunciation self-assessment 1

\begin{tabular}{ll}
\hline Total & 130
\end{tabular}

\section{Discussion and conclusion}

This study aimed to display the research tendency of English (L2) pronunciation teaching by analyzing the articles related to English (L2) pronunciation published in fourteen foreign language learning and teaching related international journals between the years of 2012 and 2017. Firstly, the results of this study indicated that quantitative research type was used much more than other research types. This inclination is supported by other research studies in the field of foreign language education as well (Solak, 2014; Yagiz, Aydin \& Akdemir, 2016).

Secondly, the results of this study revealed that the most frequently researched topic was the effects of instruction on L2 pronunciation. However, the least frequently researched topics were 'accent and identity relationship', 'non-native EFL learners' pronunciation strategies', 'the effect of study abroad context on nativelike pronunciation' and 'the effects of native and non-native teachers of English on learners' pronunciation performance'. Knowing that the effects of instruction on L2 pronunciation is the most popular research topic is very beneficial for EFL teachers because this knowledge can motivate them to give more importance to teaching L2 pronunciation in their EFL classroom.

Thirdly, it was seen that undergraduate students were the most frequently used target population by the researchers. This result is in line with previous research studies (Solak, 2014; Yagiz, Aydin \& Akdemir, 2016). Fourthly, it was seen that non-probability sampling method was the most frequently used sample selection method. This result is in line with previous research studies (Alper \& Yurdagul, 2015). Fifthly, it was found that the sample size of 31-100 was mainly used by researchers. This result provided evidence in support of previous research studies in other disciplines (Uzunboylu \& Asiksoy, 2014).

Sixthly, it was found that quantitative research method was used much more than other research types. This inclination is supported by other research studies in other disciplines as well (Arık \& Turkmen, 2009). Knowing that quantitative research method is the most commonly utilized method is very useful for the professionals in the field of ELT because this knowledge can stimulate them to utilize statistics in their research studies. Thus, they can test their hypotheses and generalize their findings easily. The findings of their research studies can be more reliable and objective.

Seventhly, it was revealed that other data collection tools (e.g. picture story, picture differences task, conversation task, oral test, word / sentence / paragraph /dialogue / short story reading) were mainly used by researchers. This result is in contrast with previous research studies in other disciplines in educational sciences (Erdem, 2011; Yagiz, Aydin \& Akdemir, 2016). Eighthly, it was unearthed that descriptive analysis method was primarily utilized by researchers. This result is in line with previous studies (Yagiz, Aydin \& Akdemir, 2016).

Ninthly, the results of this study showed that all of the articles were written in English. Knowing that all the articles were written in English is very beneficial for EFL teachers since this knowledge can help 
them to see that English is a lingua franca and that it is a very valuable tool for publishing papers in international journals. Tenthly, the results of this study showed that 2016 was the year when the number of published articles was the highest and that 2013 and 2015 were the years when the number of published articles was the lowest.

Eleventhly, the results of the study revealed that the majority of the articles were written by one author or two authors. Knowing that most of the articles were written by one author or two authors is very useful for the professionals in the field of ELT because this knowledge can motivate them to write not only individual papers but also joint papers on L2 pronunciation teaching. This result is in line with previous studies in other disciplines (Uzunboylu \& Asiksoy, 2014). Twelfthly, the results of the study revealed that the majority of the articles had refererences between 31-60. This result is also in line with previous studies in other disciplines (Uzunboylu \& Asiksoy, 2014). Thirteenthly, the key words like 'pronunciation', 'foreign accent / accentedness', 'pronunciation teaching / pronunciation instruction / pronunciation training' were found to be the most frequently utilized keywords in the evaluated articles.

Finally, we believe that the present research will stimulate more EFL teachers to integrate English (L2) pronunciation teaching into their teaching in their EFL classroom and push more researchers to do content analyses of published articles related to four language skills such as listening, speaking, reading and writing as well as language components such as vocabulary and grammar since research studies on the content analyses of these subject areas are either very few in number or non-existent in the current literature.

\section{References}

Ahmed, H.D. \& Asiksoy, G. (2018). Flipped classroom in language studies: A content analysis of recent articles. Near East University Online Journal of Education (NEUJE), 1(1), 11-19.

Akaydın, S. \& Çeçen, M.A. (2015). A Content Analysis on Articles Related to Reading Skills. Education and Science, 40(178), 183-198.

Alper, A. \& Yurdagul, C. (2015). Trends in articles related to ICT supported language learning in BJET: Content analysis. Journal of Instructional Technologies \& Teacher Education, 4(2), 1-15.

Alptekin, C. \& Tatar, S. (2011). Research on foreign language teaching and learning in Turkey (20052009). Language Teaching, 44(3), 328-353.

Arık, R.S., ve Türkmen, M. (2009). An Analysis of Articles in Scientific Journals Published in the Field of Educational Sciences. The First International Congress of Educational Research, Çanakkale.

Arslan, N. \& Kartal, E. (2018). A Qualitative Analysis of Articles on The Subject of Assessment and Evaluation i Foreign Language Teaching in Turkey. RumeliDE Dil ve Edebiyat Araştırmaları Dergisi, (12), 309-322.

Avalos, B. (2011). Teacher professional development in Teaching and Teacher Education over ten years. Teaching and Teacher Education, 27, 10-20.

Binte Habib, R. (2013). (Un) Intelligibility in EIL Pronunciation: An Analysis. IOSR Journal of Humanities and Social Science (IOSR-JHSS), 14, 21-26.

Celce-Murcia, M. and J. Goodwin. (1991). 'Teaching Pronunciation' in Celce-Murcia, M. (ed.) Teaching English as a Second or Foreign Language. Boston: Heinle \& Heinle Publishers, p.p:136153. 
Couper, G. (2008). The short and long-term effects of pronunciation instruction. Prospect, 21, 46-66.

Demir, Y. \& Koçyiğit, M. (2018). A Systematic Review of Research on English Language Teacher Education Published in Three Flagship Journals (1997-2016). Journal of Educational Theory and Practices Research. 4(1), 128-138.

Demirezen, M. (2005). "The / o / and / ow / Contrast: Curing a Fossilized Pronunciation Error of Turkish Teacher Trainees of the English Language", Çankaya University, Journal of Arts and Sciences, Vol. 1, Number 3, May 2005, 71-84.

Dewitt-Brinks, D. \& Rhodes, S. (1992). Listening instruction: A qualitative meta-analysis of twentyfour selected studies. Paper presented at the Annual Meeting of the International Communication Association (42nd, Miami,FL, May 20-25, 1992).

Erdem, D. (2011). An investigation of the selected articles between 2005-2006 in educational sciences in Turkey in terms of certain features: a descriptive analysis. Journal of Measurement and Evaluation in Education and Psychology, 2(1), 140-147.

Filiz, S. \& Benzet, A. (2018). A Content Analysis of the Studies on the Use of Flipped Classrooms in Foreign Language Education. World Journal of Education, 8(4), 72-86.

Fraser, H. (2000). Coordinating improvements in pronunciation teaching for adult learners of English as a second language. Canberra: Department of Education, Training and Youth Affairs.

Gebhard, J.G. (1996). Teaching English as a foreign or second language. Michigan: The University of Michigan Press.

Geylanioglu, S. \& Dikilitas, K. (2012). Pronunciation Errors of Turkish Learners of English: Conceptualization Theory as a Teaching Method. The Journal of Language Teaching and Learning, 2(1), 38-50.

Gilakjani, A.P. (2012). A Study of Factors Affecting EFL Learners' English Pronunciation Learning and the Strategies for Instruction. International Journal of Humanities and Social Science, 2(3), 119,128.

Goswami, U. (2000). Phonological and lexical processes. In M.L. Kamil, P.B. Mosenthal, P.D. Pearson \& Barr, R (Eds.). Handbook of reading research (pp.251-267). Mahwah, NJ: Lawrence Erlbaum Associates.

Harmer, J. (2001). The practice of English language teaching. London: Longman.

Hismanoglu, M. (2004). Problematic English consonants and vowels for Turks in relation to ELT: Text development and problem solutions. Unpublished Doctoral Dissertation, Hacettepe University, Ankara.

Hismanoglu, M. (2006). Current Perspectives on Pronunciation Learning and Teaching. Journal of Language and Linguistic Studies, 2(1), 101-110.

Hismanoglu, M. (2019). Teaching pronunciation. In Yaman, İ, Ekmekci, E., \& Senel, M. (Eds.). Basics of ELT (pp. 386-416). Ankara: Blackswan Publishing.

Hussein, G. (2015). A content analysis evaluation of The Journal of Teaching English with Technology (TEwT) between the years of 2008 \& 2013. Procedia - Social and Behavioral Sciences, 191, 31-36.

İnal, D., Özdemir, E., Kıray, G. \& Oral, Y. (2016). Review of doctoral research in English language teaching and learning in Turkey (2009-2013). Language Teaching, 49(3), 390-410. 
Isaacs, T. (2009). Integrating form and meaning in L2 pronunciation instruction. TESL Canada Journal, 27, 1-12.

Jenkins, J. (2004). Research in teaching pronunciation and intonation. Annual Review of Applied Linguistics 24,109-125.

Ketabi, S. \& Saeb, F. (2015). Pronunciation teaching: Past and present. International Journal of Applied Linguistics and English Literature, 4(5), 182-189.

Kleinsasser, R. C. (2013). Language teachers: Research and studies in language(s) education, teaching, and learning in Teaching and Teacher Education, 1985-2012. Teaching and Teacher Education, 29, 86-96.

Koçyiğit, M. \& Erdem, C. (2018). A content analysis of graduate research on English preparatory programs at universities. International Journal of Human Sciences, 15(3), 1466-1480.

Levis, J.M. (2005). Changing contexts and shifting paradigms in pronunciation teaching. TESOL Quarterly, 39, 369-377.

Martinsen, R., Alvord, S.M. \& Tanner, J. (2014). Perceived Foreign Accent: Extended Stays Abroad, Level of Instruction, and Motivation. Foreign Language Annals, 47(1), 66-78.

Ministry of Education (MoE). (2018). English curriculum for high schools (9th, 10th, 11th and 12th Grades). [Available online at: http://mufredat.meb.gov.tr/Dosyalar/201812020472656OGM\%20INGILIZCE\%20PRG\%2020.012018.pdf ], Retrieved on June 15, 2018.

Ministry of Education (MoE). (2018). English curriculum for primary and secondary schools ( 2nd, 3rd, 4th, 5th, 6th, 7th and 8th Grades). [Available online at: http://mufredat.meb.gov.tr/Dosyalar/201812411191321 İNGILIZZCE\%20ÖĞRETIM\%20PROGRAMI\%20Klasörü.pdf ], Retrieved on June 25, 2018.

Mutlu, G. (2015). Strategy training in language learning: A review of available research in Turkey. Necmettin Erbakan University Journal of Social Science, 1(1), 35-58.

Özmen, K. S., Cephe, P. T. \& Kınık, B. (2016). Trends in doctoral research on English language teaching in Turkey. Educational Sciences: Theory and Practice, 16(5), 1737-1759.

Parsons, S.A. \& Gallagher, M.A. (2016). Journal of Literacy Research, 48(4), 476-502.

Piske, T. , Flege, J.E. \& MacKay, I.R.A.(2001). Factors affecting degree of foreign accent in an L2: A Review. Journal of Phonetics, 29(2), 191-215.

Rajadurai, J. (2007). Intelligible pronunciation: Focus on the proficient L2 speakers. The Journal of Asia TEFL 4(1), 1-25.

Richards, J., \& Rodgers, T. (2001). Approaches and methods in language teaching. Cambridge: Cambridge University Press.

Setter, J. (2006). Speech rhythm in world Englishes: The case of Hong Kong. TESOL Quarterly, 40, 763-782.

Solak, E. (2014). The Content Analysis of the Research Papers on Foreign Language Education in Turkey. International Journal of English and Education, 3(3), 167-178.

Sozbilir, M., Kutu, H., \& Yasar, M.D. (2012). Science education research in Turkey: A content analysis of selected features of papers published. In J. Dillon \& D. Jorde (eds.), The World of Science Education: Handbook of Research in Europe (pp. 1-35). Rotterdam: Sense publishers. 
Tanner, J.D. (2012). Factors affecting the acquisition of pronunciation: Culture, motivation and level of instruction (Master's thesis). Retrieved from BYU Scholars Archive.

Umera-Okeke, N. (2008). Spelling and phonetic inconsistencies in English: A problem for learners of English as a foreign/second language. African Research Review, 2(1), 64-83.

Uysal, S. \& Madenoglu, C. (2015). A content analysis of scientific research studies on technology leadership in Turkey. Procedia-Social and Behavioral Sciences, 191, 37-43.

Uzunboylu, H. \& Asiksoy, G. (2014). Research in Physics education: A study of content analysis. Procedia - Social and Behavioral Sciences, 136, 425-437.

Varasarin, P. (2007). An action research study of pronunciation training, language learning strategies and speaking confidence. Unpublished doctoral dissertation, Victoria University, Thailand.

Vélez-Rendón, G. (2002). Second language teacher education: A review of the literature. Foreign Language Annals, 35(4), 457-467.

Yağız, O.,Aydın, B.,Akdemir, A.S. (2016). ELT research in Turkey: A content analysis of selected features of published articles. Journal of Language and Linguistic Studies, 12(2), 117-134.

Zhang, Q. (2009). Affecting factors of native-like pronunciation: A literature review. Korea Education \& Research Institute, 27(2), 33-52.

\title{
İngilizce sesletim öğretimi ile ilgili makaleler üzerine bir içerik çözümlemesi
}

\begin{abstract}
Özet
Bu çalışma İngilizce sesletim öğretimi ile ilgili 2012-2017 yılları arasında yayınlanmış makaleleri çözümlemeyi amaçlamıştır. Bu amaca ulaşmak için yabancı dil öğrenimi ve öğretimi alanında tanınmış ondört uluslararası dergideki 106 makale incelenmiştir. Bu ondört uluslararası dergi uluslararası platformlardaki veri tabanlarında SSCI ( $\mathrm{f}=7)$, ERIC $(\mathrm{f}=4)$, EBSCO $(\mathrm{f}=2)$ ve MLA $(\mathrm{f}=1)$ tarafindan indekslenmektedir. Makaleler araştırma türü, araştırma konusu, hedef kitle, örneklem seçme yöntemi, örneklem büyüklügü, araştırma yöntemi, veri toplama yöntemi, veri çözümleme yöntemi, makalelerin yazıldığı dil, yayınlanma yılı, yazarlar, kaynak sayısı ve en çok kullanılan anahtar sözcükler açısından çözümlenmiştir. Makalelerin içeriği hakkında veri toplamak için Sözbilir, Kutu \& Yasar (2012) tarafından geliştirilen ve İngiliz Dili Eğitimi alanına Yagiz, Aydin ve Akdemir (2016) tarafından uyarlanan makale sınıflandırma formu kullanılmıştır. Sonuçlar uluslararası bağlamlardaki İngilizce sesletim öğretimi ile ilgili araştırmaların genel kapsamını göstermiştir
\end{abstract}

Anahtar sözcükler: İngilizce (L2); sesletim; öğretim; içerik çözümlemesi; sesletim öğretimi

\section{AUTHOR BIODATA}

Murat Hismanoglu is the head of the English Language and Literature Department at Usak University, Faculty of Arts and Science, Usak, Turkey. He teaches general English to B.A students in different faculties of Usak University. He is interested in English (L2) pronunciation teaching, web-based language instruction and mobile language instruction. 